\title{
INFLUENCE OF Majorana hortonsimas BY-PRODUCT AS FEED SUPPLEMENTATION ON EWES MILK PRODUCTION AND THE GROWTH PERFORMANCE AND THEIR OFFSPRING
}

\author{
K.I. Mohamed ${ }^{1}$, A.H. Mohamed ${ }^{1}$ and Safa $\mathrm{Nady}^{2}$ \\ 1-By-Products Research Department, 2- Sheep and Goat Research Department, \\ Animal Production Research Institute, Agricultural Research Center, Giza, Egypt
}

\section{SUMMARY}

This study was carried out to investigate the effect of Majorena Hortonsimas byproduct (MHBP) as feed supplementation on digestibility, milk yield and their offspring performance. Fifteen ewes before lambing averaged $45.3 \mathrm{~kg}$ live body weight (LBW) and aged 3-4 years were divided randomly into three similar groups. The first ration (R1) consisted of concentrate feed mixture (CFM) (2\% of live body weight) and been straw without feed supplementation as control group, whereas the second and third groups received the control ration with 50 or $100 \mathrm{gm} / \mathrm{head} /$ daily of Majorena Hortonsimas by-product (MHBP) as feed supplementation as group R2 and $R 3$ groups, respectively.

Results showed that significant $(P<005)$ improvement in digestibility coefficients of OM; CP; CF; NFE and nutritive values as TDN and DCP for supplementation groups compared with control group. Group R3, showed the highest value for the digestion coefficients and mutritive value. Meanwhile there were no significant differences between $R 2$ and $R 3$ groups. Milk production was estimated by measuring the production of one day once a week for each ewe. Lambs were weighed at birth and afterwards every two weeks until weaning. The results showed that milk production was higher $(P<0.05)$ for $R 2$ and $R 3$ groups. Also, results showed that milk production was higher $(P<0.05)$ for $R 3$ group as compare with $R 2$ group during the first 8 weeks. Meanwhile, there were no significant differences between tested groups concerning birth weight. On the meantime the average body weight at the weaning was higher $(P<0.05)$ for $R 3$ as compare with control group. Also, the average daily gain for lambs from birth up to weaning for $R 3$ group was higher $(P<0.05)$ as compared with R1 group. In conclusion, Majorena Hortonsimas byproduct (MHBP) supplementation to ewes rations could be recommended for lactating ewes rations which can improve ewes to enhance milk production and lambs growth.

Keywords: Majorena Hortonsimas by-product; nutrient digestibility, milk yield, birth weight, average daily gain

\section{INTRODUCTION}

Volatile oil industry products from Aromatic plants, represent one of the most promising industries during the last 20 years in Egypt. A varying quantities of agroindustrial afford valuable supplementary ingredients to be used in animal rations

Issued by The Egyptian Society of Animal Production 
could be produced. Therefore, studies concerned with the potential supply, availability as feed, and nutritive value of these products enabling better utilization at small farm level are of prime importance for livestock development in Egypt. Aromatic plants by-products, remain after ethnic volatile oil distillation. Egypt had 55.000 feddan cultivated by aromatic plants produce approximately 100.000 Tons/year of by-products (Ministry of Agriculture, 2005) contained (DM basis) 81.32 to $87.54 \%$ crude protein 9.7 to $13.52 \%$, ether extract 1.34 to $5.87 \%$, crude fiber 22.56 to $32.50 \%$, nitrogen free extract 23.67 to $46.24 \%$ and ash 4.7 to $12.34 \%$. Wideneki et al. (1998). Some study evaluated the supplementation of aromatic plants by-products to calves ration ( Wojcik et al ., 1984), to cows ration (Tiwari et al., 1996) and sheep ration (Djouvinov et al ., 1997 and Mohamed et al., 2005).

The objective of this study was to evaluate effects of Majorena Hortonismas byproduct (MHBP) as feed supplement on digestion coefficients, nutritive values, milk production of ewes and their offspring performance.

\section{MATERIALS AND METHODS}

This study was carried out at Sids Experimental Research Station, Animal Production Research Institute, Agricultural Research Center (Bani Soaif Governorate). Fifteen ewes averaged $45.90 \mathrm{~kg}$ live body weight and aged 3-4 years, before lambing. Animal were allotted at random into three similar groups ( 5 animals each), and received one of the tested diets. The control group (RI), received the control ration, which composed of concentrate feed mixture (CFM)* and been straw (BS). The tested groups were fed on control ration and BS plus Majorena Hortonsimas by-product (MHBP) supplementation at 50 or $100 \mathrm{~g} / \mathrm{head} /$ day, for R2 and R3 groups, respectively. Animals were fed according to NRC, (1989) allowances for sheep. Fresh water was always available and animals were under veterinary care during the whole experimental period. Feed conversion was calculated and expressed in terms of DM $(\mathrm{g})$, TDN $(\mathrm{g})$ and DCP $(\mathrm{g})$ required for producing one $(\mathrm{kg})$ of milk. At the end of the study a simple economical cost evaluation was calculated for the tested diets according to the prevailing prices of feeds during the time of the experiment .

Three digestion trials were conducted with three mature Saeidi male sheep (average body weight $49.5 \mathrm{~kg}$ ) to determine rations nutrients digestion coefficients, nutritive values and some rumen liquor parameters of the previous experimental rations. Each trial lasted for two weeks as preliminary period followed by one week for feed intake determination and feed refusles sampling and feces ( as collection period). Animals were fed twice daily at 8.00 a.m. and 3.00 p.m. and refusal were recording every days. Daily feces were weighted, 10\% sampled and analyzed. Fresh water was available and animals were under veterinary care. The chemical composition of ingredients used and experimental diets are presented in Table (1).

\section{Chemical analysis}

Representative samples of feeds and feces were air dried and kept for chemical analysis according to A.O.A.C.( 1999). The data were statistically analyzed to test the significance of treatment employing the analysis of variance producer according to Snedecor and Cochran (1980). Duncan's multiple range test was applied to test significant among means (Duncan, 1955). 


\section{RESULTS AND DISCUSSION}

Chemical analysis, digestion coefficients and nutritive values:

The chemical analysis of ingredients and calculated nutrients contents for experimental diets are presented in Table (1). The Majorena Hortonsimas byproduct (MHBP) had slightly lower CP and NFE content with higher content of $\mathrm{CF}$ as percentage compared with different meals.

Table 1. Chemical analysis of ingredients and calculated experimental diets

\begin{tabular}{cccccccc}
\hline Chemical analysis & \multicolumn{7}{c}{ Chemical analysis } \\
\cline { 2 - 8 } Ingredients & DM & OM & CP & CF & EE & NFE & Ash \\
\hline CFM & 91.63 & 1.28 & 5.25 & 11.45 & 2.86 & 1.72 & 8.72 \\
BS & 90.52 & 87.64 & 4.45 & 3.38 & 1.64 & 8.17 & 2.36 \\
MHM & 0.12 & 80.59 & 18.56 & 20.72 & 2.16 & 39.15 & 19.41 \\
\hline
\end{tabular}

Digestibility coefficients and nutritive values:

Digestibility coefficients and nutritive values for the experimental diets are presented in Table (2). Digestion coefficients of CF, and NFE for R2 and R3 groups, were significantly $(\mathrm{P}<0.05)$ higher as compared with control group.But digestion coefficients of $\mathrm{DM}, \mathrm{OM}$ and $\mathrm{CP}$ for $\mathrm{R} 3$ group were significantly $(\mathrm{P}<0.05)$ higher as compared with the control group. Meanwhile, there were no significance differences between groups concerning digestion coefficient of EE. The improvement ranged between 7.23-11.84\%; $6.12-11.60 \% ; 4.74-7.81 \% ; 4.87-7.33 \%$ and $5.37-$ $7.61 \%$ for CP, CF, NDF and NFE digestibility, respectively for R2 and R3 groups.

Table 2. Digestion coefficients and nutritive values of experimental rations

\begin{tabular}{|c|c|c|c|}
\hline \multirow[t]{2}{*}{ Items } & \multicolumn{3}{|c|}{ Experimental rations } \\
\hline & R1 & R2 & R3 \\
\hline \multicolumn{4}{|l|}{ Digestible coefficients } \\
\hline DM & $59.82^{\mathrm{b}}$ & $62.45^{\mathrm{ab}}$ & $64.18^{\mathrm{a}}$ \\
\hline $\mathrm{OM}$ & $64.17^{\mathrm{b}}$ & $66.22^{\mathrm{ab}}$ & $67.56^{\mathrm{a}}$ \\
\hline $\mathrm{CP}$ & $65.72^{\mathrm{b}}$ & $68.45^{\mathrm{ab}}$ & $70.28^{\mathrm{a}}$ \\
\hline $\mathrm{CF}$ & $53.36^{\mathrm{b}}$ & $57.52^{\mathrm{a}}$ & $58.77^{\mathrm{a}}$ \\
\hline EE & 79.33 & 80.22 & 81.18 \\
\hline NFE & $71.52^{\mathrm{b}}$ & $74.72^{\mathrm{a}}$ & $77.28^{\mathrm{a}}$ \\
\hline \multicolumn{4}{|l|}{ Nutritive values } \\
\hline TDN & $61.46^{\mathrm{b}}$ & $65.24^{\mathrm{a}}$ & $67.28^{\mathrm{a}}$ \\
\hline $\mathrm{DCP}$ & $8.54^{\mathrm{b}}$ & $9.00^{\mathrm{a}}$ & $9.37^{\mathrm{a}}$ \\
\hline
\end{tabular}

$\mathrm{a}$, , b Means in the same raw having different significantly different $(\mathrm{P}<0.05)$

The nutritive values expressed as TDN and DCP wed was a reflectation the nutrients digestibility. The nutritive values for R2 and R3 groups were significantly $(\mathrm{P}<0.05)$ improved as compared with control group. These results are in agreement with those reported by Wojcik et al. (1984); Djouvinov et al. (1997) and Mohamed et al. (2005) who observed that the inclusion of some chamomile by-products (CC) within sheep rations, improved the digestibility and nutritive value. These results support the observations of Wideneki et al. (1998) and Mohamed and Ibrahim (2003) who mentioned that the improvement in rumen fermentation and nutritive values of the diets contained chamomile cake (CC) were due to the effective biochemical groups in the $\mathrm{CC}$. 


\section{Feeding trials:}

Data concerning milk yield are presented in Table (4) and Figures (1 and 2). The total milk yield TMY $/ \mathrm{kg}$ obtained during first 8 weeks of the lactation period of ewes, were significantly $(\mathrm{P}<0.05)$ increased in $\mathrm{R} 2$ and $\mathrm{R} 3$ and groups as compared to $\mathrm{R} 1$ group. On the mean time, there were no significant differences in TMY between $\mathrm{R} 1$ and R2 groups during the last 6 weeks of lactation period. As a consequence, significant differences in the total TMY were detected between R2 and R3 groups and control group during the last 6 weeks of lactation period. On the other hand the average daily milk yield (ADMY g/day), almost followed the same trend.

Table 3. Effect of experimental rations on milk production

\begin{tabular}{lccc}
\hline & \multicolumn{3}{c}{ Experimental rations } \\
\cline { 2 - 4 } Items & R1 & R2 & R3 \\
\hline No. of ewes & 5 & 5 & 5 \\
Av. body W. kg & 46.5 & 45.6 & 45.5 \\
Milk yield kg & & & \\
First 8 weeks & 23.8 & 27.00 & 30.00 \\
Last 6 weeks & 15.12 & 17.22 & 18.90 \\
Av. daily Milk yield g & & & \\
First 8 weeks & $425^{\mathrm{c}}$ & $480^{\mathrm{b}}$ & $535^{\mathrm{a}}$ \\
Last 6 weeks & $360^{\mathrm{b}}$ & $410^{\mathrm{ab}}$ & $450^{\mathrm{a}}$ \\
Total Milk yield kg & $38.20^{\mathrm{b}}$ & $44.22^{\mathrm{ab}}$ & $48.90^{\mathrm{a}}$ \\
Av. DMY g & $388^{\mathrm{b}}$ & $445^{\mathrm{ab}}$ & $493^{\mathrm{a}}$ \\
\hline
\end{tabular}

a,b Means in the same raw having different significantly differ $(\mathrm{P}<0.05)$

The ADMY g/h obtained during first 8 weeks of lactation period of ewes fed R2 and $\mathrm{R} 3$ rations were significantly $(\mathrm{P}<0.05)$ increased as compared with $\mathrm{R} 1$ ration. Also, a higher ADMY during the last 6 weeks of lactation period, obtained from animal fed R3 ration (450g/day) whereas, the lower ADMY obtained from animal fed $\mathrm{R} 1$ ration ( $388 \mathrm{~g} /$ day).

On the meantime, the ADMY for the whole period (14 weeks) for the animals fed R2 and R3 diets were significantly $(\mathrm{P}<0.05)$ higher than animal fed R1 ration. It was noticed that the supplementation with 50 or $100 \mathrm{~g} / \mathrm{head} /$ day of (MHBP) improved ewes performance. As a result to the improvement of ADMY, the TMY was increased by 9.20 and $18.0 \%$ for R2 and R3 groups, respectively than the control group during the whole lactation period. These results are in agreement with the findings of Wojcik et al. (1984) and Tiwari et al . (1996).

Data concerning the average body weight (BW) and average daily gain (ADG) for lambs from birth up to third month in the current study are shown in Table (5). The birth weight ranged between $(3.0-3.50 \mathrm{~kg})$. The highest birth weight was found with lambs of R3 group. On the meantime, the (ADG) for offspring from birth up to the first month for lambs of $\mathrm{R} 2$ and $\mathrm{R} 3$ groups, were significantly $(\mathrm{P}<0.05)$ higher than lambs for R1 group. Also, the (ADG) for offspring from the first month up to the second month followed the same trend. 
Table 4. Effect of experimental rations on average daily gain of lambs

\begin{tabular}{|c|c|c|c|}
\hline \multirow[t]{2}{*}{ Items } & \multicolumn{3}{|c|}{ Experimental rations } \\
\hline & R1 & $\mathbf{R 2}$ & $\mathbf{R 3}$ \\
\hline Birth weight, kg & 3.25 & 3.00 & 3.35 \\
\hline Birth weight, $\mathrm{kg} \mathrm{w}^{0.75}$ & $2.42^{\mathrm{b}}$ & $2.30^{\mathrm{a}}$ & 2.56 \\
\hline First month w kg, & $7.10^{\mathrm{b}}$ & $7.50^{\mathrm{ab}}$ & $9.40^{\mathrm{a}}$ \\
\hline First month w kg, w ${ }^{0.75}$ & $4.10^{\mathrm{b}}$ & $4.50^{\mathrm{ab}}$ & $4.90^{\mathrm{a}}$ \\
\hline Av. daily gain $g$ & $161^{\mathrm{B}}$ & $185^{\mathrm{aB}}$ & $240^{\mathrm{a}}$ \\
\hline Second month w kg, & $11.8^{\mathrm{b}}$ & $13.30^{\mathrm{ab}}$ & $15.20^{\mathrm{a}}$ \\
\hline Second month w kg, w ${ }^{0.75}$ & $5.77^{\mathrm{b}}$ & $6.83^{\mathrm{a}}$ & $6.53^{\mathrm{a}}$ \\
\hline Av. daily gain $g$ & $130^{\mathrm{c}}$ & $163^{a}$ & $145^{\mathrm{ab}}$ \\
\hline Weaning $\mathrm{w} \mathrm{kg}$, & $15.40^{\mathrm{c}}$ & $17.30^{\mathrm{a}}$ & $18.25^{\mathrm{ab}}$ \\
\hline Av. daily gain $g$ & 145 & 163 & 190 \\
\hline
\end{tabular}

$\mathrm{a}, \mathrm{b}$ Means in the same raw having different significantly differ $(\mathrm{P}<0.05)$

Meanwhile the body weight (BWt) of lambs at the first and second months of age for R3 group were significantly $(\mathrm{P}<0.05)$ higher than those of $\mathrm{R} 1$ group lambs as a result to the improvement of $\mathrm{ADG}$ for lambs. On the mean time, there were no significant differences between R1 and R2 groups lambs concerning the BWt at the third month. Dietary (MHBP) supplementation had significant effects on average daily gain.

Data concerning the feed intake, feed efficiency and feeding costs were shown in Table (5). The higher intake of TDN and DCP recorded for animal fed R3 ration, was a result to the improvement of nutritive values related to the supplemented additive.

Table 5. Effect of the experimental rations on the average feed intake, feed efficiency and feeding costs

\begin{tabular}{lccc}
\hline Items & \multicolumn{3}{c}{ Experimental rations } \\
\cline { 2 - 4 } & R1 & R2 & R3 \\
\hline Av. body weight kg & 46.5 & 45.6 & 45.0 \\
Av.daily milk yield g & $388 \mathrm{~b}$ & $455 \mathrm{ab}$ & $493 \mathrm{a}$ \\
Av. Feed intake, g & & & \\
DMI g & 1565 & 1630 & 1690 \\
TDN g & 962 & 1063 & 1146 \\
DCP g & 134 & 147 & 158 \\
Feed conversion & & & \\
DM / kg milk & $4.03^{\mathrm{a}}$ & $3.58^{\mathrm{b}}$ & $3.43^{\mathrm{b}}$ \\
TDN / kg milk & $2.48^{\mathrm{a}}$ & $2.34^{\mathrm{b}}$ & $2.33^{\mathrm{b}}$ \\
DCP / kg milk & $345^{\mathrm{a}}$ & $323^{\mathrm{b}}$ & $321^{\mathrm{a}}$ \\
Feeding cost & & & \\
Av. feed cost / head / day LE & $1.30 \mathrm{a}$ & 1.40 & 1.50 \\
Total feed cost during lactation & 127.4 & 137.2 & 147.0 \\
period LE & \multicolumn{3}{c}{} \\
Av. feed cost / kg milk & 3.35 & 3.10 & 3.000 \\
\hline a b , Means in the same raw having different significantly differ $(\mathrm{P}<0.05)$ &
\end{tabular}


Concerning the feed efficiency, results in Table (6) revealed that the values were 4.0, 3.58, and 3.43kg DM intake / $\mathrm{kg}$ milk, 2.48, 2.34, and $2.33 \mathrm{~kg}$ TDN intake / $\mathrm{kg}$ milk, and 345, 323 and $321 \mathrm{~g}$ DCP intake / kg milk for R1, R2, and R3, respectively. The (MHBP) supplementation at 50 and $100 \mathrm{~g} /$ head resulted in better feed efficiency rate for R2 and R3, groups. Meanwhile, the feed efficiency expressed as DM, TDN and DCP were recorded the lower value for R1 group. Such improvement of feed efficiency in tested groups (R2 and R3) may reflect the obtained results of digestibility and nutritive values of these rations. However, this beneficial effect which can be attributed to (MHBP) supplementation.

The feed cost LE/kg milk, was reduced as result to the (MHBP) supplementation, whereas the lowest value for feed cost LE / $\mathrm{kg}$ milk was recorded for R3 group. These results were reported by Mohamed et al. (2005) who observed that the feeding cost was decreased as a result to using chamomile cake CC.

In conclusion it is apparent that MHBP supplementation could be used successfully and economically by supplementing 50 or $100 \mathrm{~g} /$ head of ewes diets according to the availability of this material and production circumstances, which improves digestibility, nutritive value and feed efficiency which are mostly reflected improvement ewes performance.

\section{REFERENCES}

A.O.A.C., 1999. Association of official Agricultural chemists. Official Methods of Analysis $16^{\text {th }}$ ed A.O.A.C, Washington, DC . USA

Djouvinov D.; D.I.; Povlov; A. lchev and E. Emev, 1997. Menthor Piperits Huds and Ocimum Bnsilicum L- ethericol by - products as roughages for sheep feeding. Animal feed science and Technology , 68: 3-4, $287-294$.

Duncan, D.B., 1955. Multiple Range and Multiple F -test.Biometrics,11:1-42.

El-Ayek M.Y., 1999 . Influence of substituting concentrate feed mixture by Nigella satlva meal on: 1-Voluntary intake, digestibility, some rumen parameters and microbial protein yield with sheep. Egyptian J, Nutrition and Feeds 2: 279.

Gabr, A.A.; S.A. El-Aouty; A.A. Zaki; F.F.Abou Ammo and E.S.I. El -Gohary, 1998.

Productive performance of lambs fed diets containing Nigella Sativa meal . Egyptian J. Nutrition and Feeds. 1 2: 97.

Mericli, A. H. 1990. The Lipophilic compounds of Matricaria chamomilla with no chamazulenel in the volatile oil. International J. of Rulde Drug Res. 28. 2:145.

Mohamed, A.H.; Nadia, M.Abd El-Bar and K. Ibrahem 2005. Incorporation of aromatic plants by-products in ruminants diets 2- effect on digestibility, rumen fermentation and ewes performance. Egyptian J. of Nutrition and Feeds, Vol. 81 Special issue, $445-460$.

Mohamed, A.H. and K. Ibrahim, 2003. Incorporation of aromatic plants by-products in ruminants diets 1 - effect of using aromatic plants by-products on digestibility, rumen fermentation and growing lambs performance. Egyptian J. of Nutrition and Feeds, Vol. 6 Special issue, 1209-1217

NRC, 1989. Nutrient Requirements of sheep. $2^{\text {nd }}$ Ed. Nat. Acad. Sci., Washington, $D C$.

Pesce, A.J. and L.A. Kaplan, 1977. Methods in clinical chemistry" The C.V. Mosby Co., St.Louis, Washington, D.C. Toronto . 
Salem, F. A. and M. R. El-Mahdy, 2001. Effect of some medicinal plants as feed additives on nutrients digestibility, rumen fermentation, blood and carcass characteristics of sheep. $2^{\text {nd }}$ Conf. of Animal Prod. \& health in Semi Arid Areas., 4-6 September, El-Arish, North Sinai, Egypt.

Siest, G., J. Henny and F. Schiele 1981. Interpretation des examens de laboratorie Karger ed. 206.

Snedecor G.w. and W.G . Cochran, 1967. Statistical Methods $7^{\text {th }}$ Ed., Iowa State University Press, Ames, Iowa, U.S.A.

Tiwari, D.P. ; C.M. Tiwari; R.K Jain; C.P. Mishra and U.K. Mishra, 1996. Nutritive evaluation of Vantulse Oscimum bascilinum Ocimum basilicum cake in Sahiwal cows Indian J.of Animal Nutrition . 13 : 3, 178- 180.

Wideneki, K.; R. Stenzel; L. Saba and H. Bis-Wencel,1998. Preliminary results of learing calves fed with mineral -herb mash for 3 months. Annales Universitatis Mariae Curie Saklodowska Sectio, EE. Zootechnica 16: 107- 112

Wojcik, S.; S. Blaziak; K.Widensk and K. Zawislak, 1984. Feeding value of some herbal by-products . Biuletyn -informacyjny Przemyshe Paszowego. 233 29-36. 


\title{
تأثير اضافة كسب البردقوش على الاداء الانتاجى للنعاج ونتاجها.
}

\section{خميس إبراهيم محمد، علاء الاين حسن محمد، صفاء نادى عبدالعظيم}

\section{معطُ بحوث الإتتاج الحيوانس، مركز البحوث الزراعية، مصر}

\begin{abstract}
تهذف هذة الدراسة الى دراسة تأثير اضافة مخلفات نبات البردقوش ( م ن ب) الناتجة من استخلاص

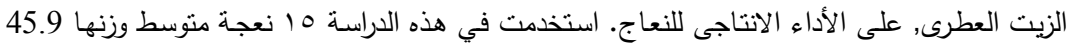

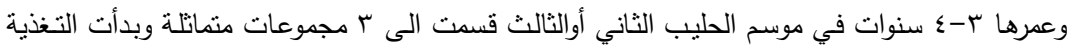

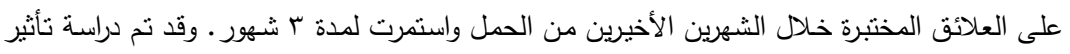

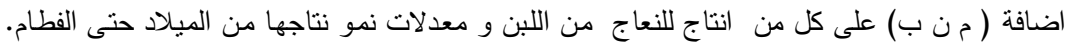

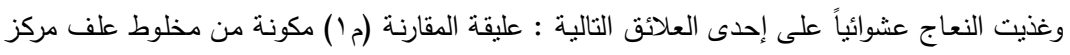

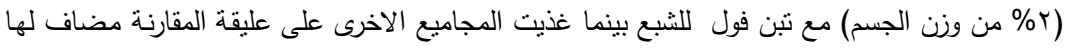

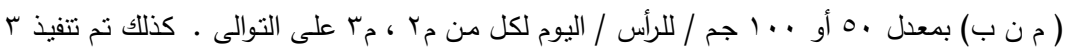
تجارب هضم لتقييم معاملات الهضم والقيمة الغذائية للعلائق المختبرة.

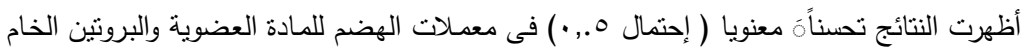

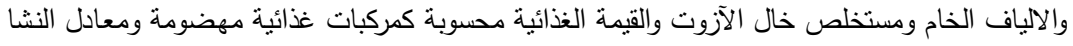

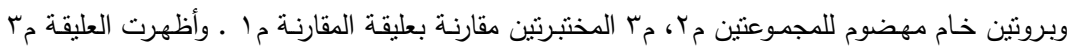

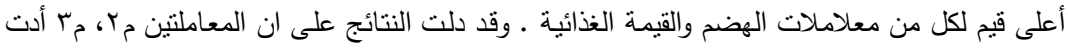

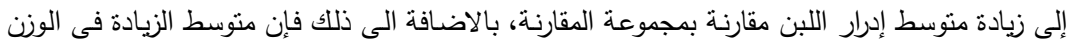

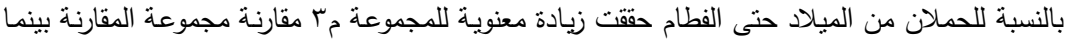

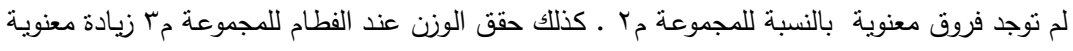
مقارنة بمجموعة المقارنة وذلك كنتيجة لزيادة معدل إنتاج اللبن • لمعند
\end{abstract}

